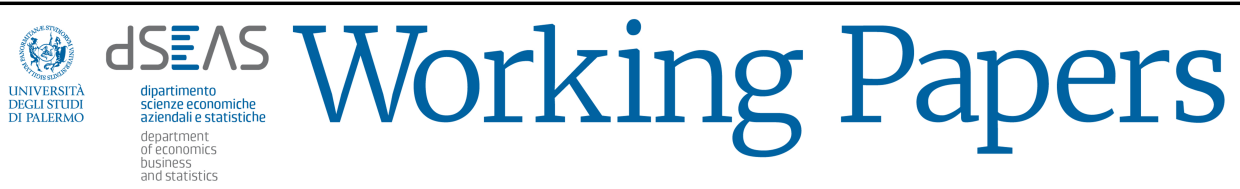

ISSN 2611-0172, volume II, 2018

\section{Accounting meets economics: towards an 'accounting view' of money}

\author{
Biagio Bossone · Massimo Costa · Andrea \\ Cuccia · Giuseppe Valenza
}

Received: date / Accepted: date

\begin{abstract}
This study lays the foundations of the "Accounting View" of money. Using international accounting principles, the study argues that state and central bank monies are not debt, and that in fractional reserve regimes only a share of commercial bank money can be regarded as debt. The study determines how the seigniorage associated with the issuance of these monies should be accounted for in the financial statements of the issuing institutions, and examines what this implies for the correct understanding of money. The new view throws light into such issues as the true nature of central bank capital, commercial banks, and digital currencies. Drawing on it, new measurements of seigniorage are derived and applied to the case of the UK (for which recent estimates exist). The results reveal that seigniorage, in particular that extracted by commercial banks, is a quantitatively relevant phenomenon.
\end{abstract}

Keywords Central bank money and capital · commercial banks · deposits · debt · equity · seigniorage.

Riassunto Questo studio pone le fondamenta dell' "Approccio Contabile" ("Accounting View") alla moneta. Sulla base dei principi di Ragioneria Generale riconosciuti internazionalmente, lo studio argomenta che le monete emesse dallo stato e dalla banca centrale non costituiscono debito e che nei regimi di riserva frazionaria soltanto una quota della moneta emessa

M. Costa, A. Cuccia, G. Valenza

Dipartimento di Scienze Economiche, Aziendali e Statistiche, Università degli Studi di Palermo

Viale delle Scienze, Edificio 13

Tel.: +39-09123895260

E-mail: massimo.costa@unipa.it

B. Bossone

Group of Lecce 
dalle banche commerciali pu essere considerata quale debito. Lo studio chiarisce come il signoraggio associato all'emissione di queste monete debba essere contabilizzato nei bilanci delle istituzioni emittenti ed esamina le implicazioni di ciò per la corretta comprensione della moneta. Il nuovo approccio fa luce su argomenti quali la vera natura del capitale della banca centrale, le monete delle banche commerciali e quelle digitali. Da esso si derivano nuovi metodi di stima del signoraggio e si applicano al caso del Regno Unito (per il quale esistono stime recenti). I risultati rivelano che il signoraggio, in particolare quelle estratto dalle banche commerciali, un fenomeno quantitativamente rilevante.

Parole chiave Moneta e capitale delle banche centrali - banche commerciali - depositi - debito - patrimonio netto - signoraggio.

\section{Introduction}

Coins circulating as legal tender in national jurisdictions worldwide are treated as debt liabilities of the issuing states and reported as a component of public debt under national accounting statistics (ESA, 2010). Similarly, banknotes issued by central banks and, by extension, central bank reserves are accounted for as debt owed by the central banks to the banknote and reserve holders, respectively. A fortiori, demand deposits issued by commercial banks to their clients are considered as debt liabilities of the issuing banks and represent the counterparts to the value held by depositors on the demand deposit accounts with those banks.

In fact, although the law says that money is "debt," a correct application of the existing accounting principles raises serious doubts about such conception of money. Debt involves obligations to transfer economic resources from borrowers to lenders (IASB, 2018). Yet, for the state, which obligation derives from the public holding coins? Or, for the central bank, which obligation derives from the holders of banknotes or the banks holding reserves? And in the case of commercial bank deposits, how does their nature of debt obligations relate to the circumstance that, in fractional reserve regimes with central banks acting as lenders of last resort, a large share of such deposits will never be redeemed for cash or other settlement instruments - with an almost absolute degree of certainty? Moreover, aren't non-debt money liabilities a source of income for their issuers (also known as "seigniorage"), which originates from the power to issue money at a cost that is lower than the attendant revenue? If so, how should issuing institutions account for these sources of income?

This study is about establishing the true nature of all the above forms of money once it is clarified that they are not debt liabilities. Proceeding separately for the case of monies issued by the state and the central bank and those issued by commercial banks and other privatesector entities (e.g., digital currencies), respectively, the study will determine the correct way to account for them in the financial statements of the issuing institutions. The study will also clarify what the different accounting treatment implies for a correct understanding of the concept of money (hence, the name of "Accounting View" of money that we propose for our approach), and will evaluate the financial implications of the new understanding. Finally, 
drawing on the implications of the new approach, the study will derive new measurements of the seigniorage extracted by the state, the central bank, and commercial banks, respectively, and will provide empirical estimates to assess the quantitative significance of seigniorage in contemporary economies.

More broadly, this study aims to resolve the apparent inconsistency between the formal rules of reporting money liabilities in the financial statements of the issuing institutions, on the one hand, and the economic substance of the money liabilities to be reported in the statements, on the other. Resolving theis inconsistency requires a dynamic interaction between Accounting and Economics - the greatest ambition of our proposed approach: only Accounting can fill in the gap, provided that Economics brings it to the open. The general lack of communication between the two disciplines has caused the inconsistency to persist unaddressed for decades.

In point of methodology, while accounting practices vary across countries, and in particular across central banks (Archer and Moser-Bohem, 2013), this study takes as reference the new Conceptual Framework for Financial Reporting (henceforth, "Framework"), which underpins the International Financial Reporting Standards (IFRS). The IFRS reflect the best wisdom that the international financial community has come to express, with a view to ensuring transparency and consistency between the form of reporting rules and the substance of the economic facts to be reported.

The study is organized as follows. Section 2 reviews the literature on the practices currently in use to account for money in the balance sheet and financial statement positions of money issuers; the section also reviews the literature on seigniorage (including that on commercial banks). Section 3 describes the new "Accounting View" of money, it shows how different types of money should be understood according to the new approach and identifies the sources of seigniorage deriving from the power to issue money; the section, then, points to how the types of money being discussed should be treated based on the relevant international accounting principles. Section 4 identifies new measurements of seigniorage and applies them to the case of the UK (for which recent estimates are available). Section 5 concludes the study.

\section{Review of the Literature}

The accounting literature on money liabilities is rather scant, as shown by the recent survey on financial accounting practices by Beatty and Liao (2014). The reason for this lack of interest by the community of scholars has historical roots: originally, money liabilities were plain debt liabilities and were allocated as such in the financial statements of the issuing institutions: there was no point in further investigating their nature. Inertia has done the rest.

On the accounting of central bank money, the only contribution that is relevant to our study is the work by Archer and Moser-Boehm, which replaces the narrow concept of equity capital with the broader one of "positive comprehensive net worth", which, in addition to conventional shareholder equity, includes the stock of banknotes outstanding and the present value of future seigniorage income. In particular as regards banknotes, the authors argue that they "... act 
more like equity capital than debt obligations. As they bear no interest and are perpetual in character, they provide a stable funding base for income generation. To the extent that net income can be retained when needed, a large share of banknote liabilities provide a base for rebuilding equity if it has been depleted by a negative shock. (pp. 33-34). Archer and MoserBoehm, however, do not dig further into this line of enquiry and do not extend the sources of income beyond banknotes, what we actually set out to do, inter alia, in this study.

No literature exists on the accounting treatment of commercial bank money (demand deposits), an issue that is totally disregarded by the international accounting standards (the International Financial Reporting Standards (IFRS) and the General Accepted Accounting Principles (GAAP)) as well as by existing national banking legislations. ${ }^{1}$ Based on the general principle of "prevalence of substance over form", it seems here that, for reasons discussed in Section 2, the "form" of debt liability has prevailed over the substance of equity capital. However, for the purpose of our study the literature on hybrid financial instruments (that is, instruments that are partly debt liabilities and partly equity capital) is highly relevant. According to PAAinE (2008), Schmidt (2013), Fargher et al. (2016), and PWC (2017), the distinction between these two basic sources of funding is no longer as neat and sharp as it used to be, and calls into question the conventional definition of equity capital as the mere algebraic difference between assets and liabilities. For a company, in fact, equity capital is a source of funding much as debt liabilities are, with the difference that, unlike the latter, equity capital is not to be refunded to the companys owners unless and until the company enters into liquidation procedures.

The tax accounting literature (Flinn, 1999), too, is relevant for the purpose of our study, as the distinction it introduces between capital gains and revenue gains allows us to apply the accounting definition of hybrid financial instruments to commercial bank money liabilities, as discussed in Section 3.2.

Finally, our study builds on Costa (2009), which shows the historical process of gradual transformation of commercial bank money from debt liability to equity capital. While this process has already been completed for coins, banknotes and central bank reserves, it is to be considered "in progress" for commercial bank money.

Money as equity presupposes that seigniorage income accrues to money issuers. As regards state and central bank seigniorage, the literature is quite well known and extended (see Baltensperger and Jordan (1997a), Haslag (1998), Burdekin (2009), and the recent comprehensive review by Bjerg (2017)). Our study introduces new components into the definition and measurement of seigniorage; it also distinguishes between primary and secondary seigniorage in a way that conceptually resembles the distinction adopted by Bjerg et al. between monetary and opportunity cost seigniorage, but uses different definitions and measurements than theirs, based on the application of correct accounting principles.

\footnotetext{
1 For example, the "Debiti verso la clientela" in Italy, the "Opérations avec la clientele" in France, and the "Customer accounts" in the U.K., are all represented as debt liabilities in accordance with their respective national legislations.
} 
Finally, concerning the seigniorage extracted by commercial banks, early references in the literature are Baltensperger and Jordan (1997b), and Bossone (2000, 2001). The topic has been quantitatively explored by Cardoso (2003), Arby (2006), Soldatos and Varelas (2015), and recently by Bjerg et al., and Macfarlane et al. (2017). As for the case of state and central bank seigniorage, our study introduces new definitions and measurements.

\section{The "Accounting View" of money}

The "Accounting View" of money reconsiders the various forms of money that are today commonly used worldwide as legal tender or as monies issued by commercial banks, and redefines their nature based on the correct application of the relevant international financial accounting principles and standards. We shall deal separately with legal tender and commercial bank money, respectively.

The approach can be applied to cryptocurrencies issued by the private sector.

\subsection{Legal Tender}

Traditionally, and for a long time, sovereigns used to guarantee that coins issued contained specific amounts of precious metals. Later, banknotes gave holders the right to claim conversion into silver or gold (Costa, 2009). A similar obligation committed central banks to their reserve liabilities issued to commercial banks. All three species of money thus originated true debt obligations that were legally binding on their issuers.

Today, convertibility has all but disappeared for all three types of money. Coins have lost most of their relevance and have largely been replaced by paper money; convertibility of banknotes was suspended long ago; and the abandonment of the gold-exchange standard (about half a century ago) marked the demise of "debt" banknotes even at the international level. Finally, the reserve deposits held by commercial banks and national treasuries at central banks are today de-linked from obligations of conversion into commodities or third-party liabilities. ${ }^{2}$ Therefore, although these monies are still allocated as debt in public finance statistics and central bank financial statements, they are not debt in the sense of carrying obligations that imply creditor rights.

Accounting treatment Issuing legal tender involves transactions whereby money is sold in exchange for other assets (even when it is exchanged against credit claims under lending contracts). The proceeds from money sales represent a form of income, specifically "revenue income." ${ }^{3}$ Issuing legal tender thus generates income to the issuer. Under current accounting

\footnotetext{
2 Except where the central bank adheres to fixed exchange rate arrangements, the economy is dollarized, or the country is under a currency board regime.

3 Income, in the most general meaning of enhancing equity, may take the form of capital income or revenue income. The former does not relate to running a business, while the latter arises from running business activities (Maheshwari, 2013).
} 
practices, this income is (incorrectly) unreported in the income statement of the central bank and is, instead, (incorrectly) set aside under the central bank's "liabilities."

In fact, when money is issued by a public-sector entity, the associated income should accrue to the entity's owners: the citizens. When, on the other hand, money is issued by a privately owned central bank, the income should accrue to the central bank's private owners. If the income is not distributed to the owners, it should go into retained earnings and become equity. This argument is consistent with that articulated by Archer and Moser-Boehm (2013).

The assimilation of money to equity requires moving beyond the distinction between equity and liabilities, as discussed in Section 2. A correct application of the IFRS recognizes that the money that is accepted as legal tender is not a financial instrument for the holder and therefore it cannot be debt for the issuer.

International Accounting Standard (IAS) 32 defines a "financial instrument" as "a contract that gives rise to a financial asset of one entity and a financial liability or equity instrument of another entity," and defines an "equity instrument" as "any contract that evidences a residual interest in the assets of an entity after deducting all of its liabilities" (par. 11). Under these definitions, legal tender money is neither "credit" for its holders nor "debt" for its issuers. It is instead net wealth of the holders and net worth (equity) of the issuers.

Money accounted as the issuer's equity implies ownership rights. These rights do not give money holders possession over the entity issuing the money (as shares giving investors ownership of a company or residual claims on the company's net assets). Rather, they are the same as those acquired by consumers purchasing goods by firms, since selling a commodity that grants specific utility to consumers is not conceptually dissimilar from selling an instrument that grants its acquires a general type of utility - that of settling financial obligations. ${ }^{4}$ They consist of claims on shares of national wealth, which money holders may exercise at any time. ${ }^{5}$ Those who receive these claims acquire purchasing power on national wealth, and those issuing these claims get in exchange a form of gross income of equal nominal value. The income calculated as

\footnotetext{
4 However, the similarity between money and goods in providing utility to holders and consumers, respectively, does not eliminate the unique features of money, such as its zero (or negligible) elasticity of production and its zero (or negligible) elasticity of substitution (Davidson, 1972).

5 An explanation is due on the use of the word "claim" in this context. If, in an economy, people conventionally agree to sell their labour services, products, and assets to one another in exchange for an intrinsically valueless object called "money", then, in force of that very same conventional agreement, people believe such money to give their holders a claim to purchase labour services, products, or assets in exchange for it. Now, such claim is not enforced by any law, it does not bind anybody to engage unwillingly in the exchange process, nor is it a claim pending upon any specific individual. Rather, it is a generalized claim on the economy at large (and all of its agents) - a claim that gives money holders the right to exchange their money holdings in transactions that take place at terms and conditions to be mutually and freely agreed between the transacting parties. In other words, saying that money is a claim on society's wealth does not mean that people are forced to sell their values in exchange for money. It means though that people must accept money if they want to sell their values. The issue at stake here is one of "prevalence of substance over form", which is typically encountered in the accounting practice.Money is not a legal, or formal, claim toward somebody, but a substantial claim over a nominally equivalent share of society's wealth. Should people not take it as such, they would not accept it in the exchange process and money would be soon worth nothing.
} 
the difference between the gross revenue from money issuance and the cost of producing money (i.e., seigniorage) is appropriated by the entity issuing the money.

Implications Several implications follow from the proposed approach. First, income from seigniorage is systematically concealed and seigniorage is not allocated to the income statement (where it naturally belongs), while it is recorded on the balance sheet under debt liabilities, thus originating outright false accounting.

Second, "primary" seigniorage, that is, the income that derives from the creation of money ex nihilo and by fiat decision should be distinguished from "secondary" seigniorage, which derives from the interest income received on the money that is issued and loaned. The state does not receive any secondary seigniorage from coins (they are not loaned), while central banks receive seigniorage from both banknotes and reserve issuances but account only for the former, not for the latter. The distinction between primary and secondary seigniorage will be the subject of empirical estimations in Section 4.

Third, central banks with the power to issue the national currency may "create" their own capital, and they can do so at any time they need to. In other words, to the extent that a central bank retains the power to issue money, it can never find itself in a position of having to request for recapitalization by the government. ${ }^{6}$ It follows that central bank independence may never be threatened by problems of under-capitalization It follows also that the "optimality" of central bank capital can be defined only in relation to the monetary policy objectives that the central bank is mandated to pursue.

Fourth, the implications above identify with clarity who would provide the ultimate backstop in a crisis situation. Discussions around the backstop function often entail a (rather paradoxical) vicious-circle argument whereby, when at stake is the risk of a government defaulting on its own debt obligations, the monetization of debt through money creation is usually considered - at least in principle - as providing the last-resort remedy to avoid default: the central bank would be the backstop in this case. On the other hand, when at stake is the risk of a central bank running into financial losses, the government is invoked as the last-resort provider of the extra capital needed to rebuild the central bank's equity position: in this case, the backstop is the government. But the two options can't both be true. The true backstop can only be the entity that holds the power to issue the currency. ${ }^{7}$

\footnotetext{
6 The power to create one's own capital is perhaps the most vivid example of what economists refer to as a "free lunch", and it derives from the power to issue fiat money. The free lunch from money issuance may be socially beneficial, if the newly created purchasing power is employed to mobilize unutilized resources and to produce new output, or it may resolve only into higher prices with no net social benefits. In this case, however, the money issuer still enjoys a free lunch in that it holds a claim on real resources that it would not hold, absent that power. The whole pie would be smaller for each eater (due to the effect on prices), but a share of it would go to the one eater who has not contributed to its preparation.

7 Buiter (2008) argues that the taxpayer, through the treasury, is the ultimate and only guarantor of central bank solvency. In fact, based on the argument above, Buiter's assertion holds in the deeper and more general sense that the backstop function can only work if there are real resources available in the economy that can be extracted from their owners through either explicit taxation or the implicit (inflation) tax inherent in money
} 
Fifth, under the accounting practices currently adopted by national governments and central banks, seigniorage is largely under-appreciated It will be necessary to identify and to estimate such seigniorage, the share of seigniorage that is returned to its legitimate "owners" (the citizens), and its effects on economic activity as well as on the economy's incentive structure and the distribution of national wealth across society. Moreover, for public finance purposes, the application of correct financial accounting principles and standards would allow to "clean up" the fiscal budgets and central bank balance sheets from the false practice of associating legal tender to "debt."

Finally, an argument could be made whereby the government should be entitled to receiving back the seigniorage extracted by the central bank from the economy (after having made provisions for covering the central bank's running and capital costs). For the reasons discussed above, this would in no way weaken the financial position of the central bank, which would always be able to operate the country's monetary policy agenda based on its underlying objectives and with not concern for its own level of equity. The use of seigniorage income by the government would be a fiscal policy decision that should be subject to the country's political process, taking into consideration distributional and macroeconomic factors, but under the principle that seigniorage income ultimately originates from, and belongs to, the wealth of the country's citizens.

\subsection{Commercial Bank Money}

Commercial bank money and central bank reserves After long being a tenet of post-Keynesian theories of money, ${ }^{8}$ even mainstream economics has recognized that commercial banks are not simple intermediaries of already existing money - they create their own money by issuing liabilities in the form of demand deposits (McLeay et al., 2014). ${ }^{9}$

creation. It should be noted, however, that even before getting to the point where real resources would be exhausted, in actual circumstances a confidence crisis in a country economy might be such that people would want to dump both government debt and cash for foreign securities, thereby neutralizing the ultimate backstop role of the central bank. Under such circumstances, the backstop function could only be provided by an external actor.

8 See, for instance, Moore $(1979,1983)$ and the literature on monetary circuit theory. As this is too vast to be cited here and do justice to its many contributors, we refer only to the work by Augusto Graziani (2003), one of the theory's most authoritative exponents. In fact, a survey into the history of economic ideas reveals important antecedents. The process by which commercial banks create money when they issue new credit was central to the thinking of prominent figures such as Knut Wicksell, Friedrich Hayek, Irving Fischer, John Maynard Keynes and Joseph Schumpeter and was an integral aspect of theories on banking and money at the beginning of the 20th century (Turner 2013, Werner 2014).

9 In a post titled Central Bankers: 'We're all Post-Keynesians now', Jesse Frederik suggests that central bankers may have grasped the reality of commercial bank money creation somewhat earlier than academics, who in their textbooks still to this day continue to subscribe to the conventional "money multiplier" story. See also the related post Who is right? Krugman or Keen or / and 9 Central Bank economists?). Interestingly, among central banker, Sir Mervyn King, former Governor of the Bank of England, addressing a conference of businesspeople once recognized that, "When banks extend loans to their customers, they create money by 
In fact, in contemporary economies the largest bulk of money is created by commercial banks (Ryan-Collins et al ., 2011).

If banks create money by lending or selling deposits, they do not need to raise deposits in order to lend or to sell deposits (Werner, 2014). ${ }^{10}$ Still, they must avail themselves of the cash and reserves necessary to guarantee cash withdrawals from clients and to settle obligations to other banks emanating from client instructions to mobilize deposits to make payments and transfers.

The relevant payment orders are only those between clients of different banks, since the settlement of payments between clients of the same bank ("on us" payments) does not require the use of reserves and takes place simply by debiting and crediting accounts held on the books of that bank. For cash withdrawals and interbank payments, every bank must determine the optimal amount of cash and reserves needed to cover deposits. These consist of: i) cash reserves and reserves deposited with the central bank; ii) reserves from settlement of incoming payments from other banks; iii) borrowings from the interbank market; iv) borrowings from the central bank; v) immediate liquidation of unencumbered assets in the balance sheet, and vi) new deposits of cash from old and new clients. ${ }^{11}$

Accounting treatment Commercial bank money constitutes a debt liability for deposit issuing banks, since they are under obligation to convert deposits into cash on demand from their clients and to settle payments in central bank reserves at the time required by payment system settlement rules.

However, in a fractional reserve regime banks hold only a fraction of reserves against their total deposit liabilities. The amounts of reserves they actually use for settling interbank obligations are only a fraction of the total transactions settled.

The more limited is the use of cash in the economy, and the larger are the economies of scale in the use of reserves (as permitted by payment system rules and clients' non-simultaneous mobilization of deposits), the lower is the volume of reserves that banks need to back up the issuance of new de-posits. ${ }^{12}$

crediting their customers' accounts." (Speech to the South Wales Chamber of Commerce at The Millenium Centre, Cardiff on 23 October 2012).

10 Banks create money by lending or selling deposits. Lending deposits features very close analogies to selling deposits. As banks issue deposits to clients in exchange for money, banks become owners of the money received and acquire the rights to use it as they wish (subject to existing laws and regulations). Even if the banks are constrained in the use of the money - such as, for instance, in the case of regulation prescribing the types of assets to be held - they (not the depositors) are the owners of the purchased assets and they (not the depositors) are the owners of the income generated by the purchased assets.

11 The new non-cash deposits from clients can only consist of deposits transferred from other banks, which fall under item ii) above.

12 For the use of cash, in cases where the monetary authority declares deposit inconvertibility and prohibits deposit transfers across borders, bank money effectively replicates central bank money, whereby reserves cannot circulate out of the central bank's books: any single commercial bank may dispossess itself of its own reserves (if some other banks demand them), but all of them cannot altogether do so since reserves once created remain outstanding until they are paid or sold back to the central bank. 
Payment system rules affect the use of reserves via two channels: the settlement modality (that is, netting or gross settlement) and the technology adopted. Modern technologies introduce elements of netting into gross settlement processes and increase the velocity of circulation of reserves, thereby allowing banks to economize on the use of reserves for any given volume and value of payments settled.

In the hypothetical case of a fully consolidated banking system in a cashless economy where all agent accounts sit with only one bank, all payments and transfers would be "on us" for the bank. The bank would need no reserves for settling transactions and would be under no debt obligation to its clients. It might create all the money that the economy could absorb without holding reserves, and its money would have the same power as legal money in settling all debts.

In real-world economies, however, there are multiple banks whose payment activities generate interbank settlement obligations. Yet, the fractional reserve regime and the economies of scale allowed both by payment system rules and by depositors' non-simultaneous mobilization of deposits reduce the volume of reserves needed by the banks to back their debts. Under increasing scale economies, banks can create more liabilities (by lending or selling deposits) with decreasing reserve margins for coverage. From the hypothetical case above and form this discussion, it follows that, all else equal, a more consolidated banking system affords lower coverage of its liabilities (and at lower cost) than a less concentrated one.

More generally, absent adverse economic or market contingencies inducing depositors to convert deposits into cash or to transfer them across banks, the liabilities represented by deposits only partly constitute debt liabilities of the issuing bank, which as such require cash and reserve coverage. The remaining part of the liabilities are a source of income for the issuing bank income that derives from the bank's power to create money. In accounting terms, to the extent that this income is undistributed, it is equivalent to equity. Total demand deposits, therefore, consist of "debt-deposits" and "equity-deposits."

The double nature of deposits is stochastic in as much as, at issuance, every deposit unit can be either a debt-deposit (if, with a certain probability the issuing bank receives requests for cash conversion or interbank settlement) or an equity-deposit (with complementary probability). Faced with such stochastic double nature of its money, a commercial bank finds it convenient to provision the deposit unit issued with an amount of reserves that equals only the expected value of the associated debt event (possibly corrected by a margin of uncertainty), rather than the full value of the deposit unit issued.

"Stochastic" refers to the fact that - ex ante - a bank creating one unit of deposit expects (probabilistically) that only a share of that unit will translate into debt, while the remaining share (still probabilistically) will not be subject to requests for conversion into cash or reserves. The share of debt-deposits (or equity-deposit as its complement) is a stochastic variable that is influenced by behavioural and institutional factors (for example, cash usage habits, payment system rules) as well as by contingent events. For example, in times of market stress, the share of debt-deposits tend to increase, while they tend to be lower when there is strong trust in the economy and the banking system in particular. Policy and structural factors that strengthen 
such trust (for example, the elasticity with which the central bank provides liquidity to the system when needed or a deposit insurance mechanism) increase the share of equity-deposits.

This argument is evident when applied to the whole banking system, but it also holds for each individual bank albeit to different extents depending on the size of each bank for a given payment settlement system and cash usage ${ }^{13}$ From the discussion so far it follows that, all else being equal, the stochastic share of debt-deposits for a small bank are greater than for a larger bank. Vice versa, the larger is the bank, the greater is the share of equity contained in its deposit liabilities.

Consistency with international accounting standards The stochastic double nature of commercial bank money is consistent with the definition of liability provided by the new Framework under IASB (2018), whereby, "a liability is a present obligation of the entity to transfer an economic resource as a result of past events" 14 and "Financial reports represent economic phenomena in words and number. To be useful, financial information must not only represent relevant phenomena, but it must also represent the substance of the phenomena that it purports to represent. In many circumstances, the substance of an economic phenomenon and its legal form are the same. If they are not the same, providing information only about the legal form would not faithfully represent the economic phenomenon. ${ }^{15}$

In light of these definitions, demand deposits are a hybrid instrument - partly debt and partly revenue. The debt part relates to the share of deposits that will (likely) be converted into banknotes on demand or into reserve for payment settlement purposes and reflects the "substance" of the obligation underlying the deposit contract. The revenue part, on the other hand, relates to the share of deposits that will (likely) never be converted into banknotes or reserves, and reflects the mere "legal form" underlying the deposit contract. Once accumulated, this revenue becomes equity.

Now, since there is no accounting standards governing hybrid revenue-liability instruments explicitly, IAS 32 applies (in force of the analogy stated in IAS 8) and provides that, in the context of a hybrid liability instrument, the debt component must be separated from the equity one. ${ }^{16}$ From operating such separation follows that, once the debt component is identified, the residual left is the equity component. ${ }^{17}$ In the case of deposits, the share of deposits that (most

\footnotetext{
13 Size here refers to the volume of payment transactions that the bank intermediates relative to the total payment transactions in the system.

14 Section 4.26 of the Framework.

15 Section 2.12. of the Framework.

16 Specifically, IAS 8 (Sections 10-11) requires that, "In the absence of an IFRS that specifically applies to a transaction, other event or condition, ... management shall refer to, and consider the applicability of, the following sources in descending order: (a) the requirements in IFRSs dealing with similar and related issues; and (b) the definitions, recognition criteria and measurement concepts for assets, liabilities, income and expenses in the Framework."

17 See IAS 32, Sections 28 et.ss. It is noteworthy that, in the case ruled by the quoted standard, the hybrid instrument has the double nature of 'liabilities-capital' and not of "liabilities-revenue:"; however, both capital and retained earnings belong to equity. Briefly, equity can be shared into at least two major components: capital
} 
probably) will not translate into debt liabilities represent retained earnings (that is, equity capital).

The application of IAS 32 is a textbook case. It implies that the financial statement of the issuing bank should report among debts only the share of deposits that give origin to a substantial obligation to transfer economic resources, while the residual share should be reported in the income statement as revenue. Moreover, since the share of profits attributable to this revenue is undistributed, it add to the bank's equity.

To support the validity of the approach here proposed, consider IAS 37 (on risk provisioning, charges and contingent liabilities). ${ }^{18}$ This standard considers as debt all commitments that fall under the Framework's definition of "liability," that is, those that generate outflows of economic resources with a probability greater than 0.5 . Below such threshold, the liability is a contingent liability and must only be reported in the notes to the financial statements.

The implication is inescapable: the existence of formal claims is not alone sufficient for a liability to be considered as debt; the essential requisite is the probable outflows of economic resources. The probability is not per se relevant, yet it is so in this case since it allows for an assessment of the faithful representation of the transactions involved. ${ }^{19}$ In the case of commercial bank money, the share of deposits that are not debt liabilities must be regarded as revenue, and since such revenue is not reported in the income statement, it constitutes retained earnings (or equity).

Implications In fractional reserve regimes, commercial bank money (that is, demand deposits) has a double nature. This originates from the power of banks to create a form of money that only partly has the nature of debt.

Some critical implications follow. The first is that a relevant share of deposits that banks report in their financial statements as "debt toward clients" generate revenues that are analogous to the seigniorage rents extracted by the state and the central bank through the issuance of legal money (coins, banknotes and central bank reserves). This, in turn, bears implications for the way banks' capital is calculated. Critical for this calculation is the probability factor discussed above, which characterizes each bank individually, depending importantly on its size (relative to the other banks of the market(s) where it operates) and its role in the payment system. Different calculations of bank capital would impact on each bank's potential to extend loans and should lead policy authorities to focus on the optimal liquidity of bank capital - an issue we are not going to pursue further here.

and other ownership's contributions, on the one hand, and retained earnings on the other. IAS 32 provides regulation for splitting hybrid instruments between a part attributable to liabilities and a part attributable to equity. Based on the definitions of the Framework, once the component recognizable as debt liability is identified, the residual component is attributed to equity.

18 See IAS 37, Sections 12-13, where the fundamental distinction is drawn between the adjective "probable" for the debt liabilities and the adjective "possible" for contingent liabilities to be reported in the notes to the financial statements.

19 See IASB (2018), Section 5.17. 
The second implication is that much as demand deposits are hybrid instruments, commercial banks are hybrid institutions, too: as issuers of debt-deposits, when they lend money they act as pure intermediaries; as issuer of equity-deposits, they are money creators. For these reasons, and for the reasons discussed above, smaller banks tend to fall within the former category, whereas larger banks belong more to the latter. Also, and importantly, while the income earned on debt-deposits originates from intermediation, the income from equity-deposits constitutes seigniorage. This distinction will be considered in our estimation procedures in Section 4. Commercial bank seigniorage represents a structural element of subtraction of net real resources from the economy, with potentially contractionary effects on profits and/or wages, distributional consequences, and frictions between capital and labour all effects that should be studied carefully. Policy considerations should be given to mechanisms that induce banks to re-inject their seigniorage income into the economy, or fiscal measures could be considered to redistribute commercial bank seigniorage across the society. Alternatively, policies could be designed to reduce seigniorage, say, by increasing banking sector competition or by limiting the average size of banks.

Another implication of the Accounting View developed above, which might become relevant especially considering the fast rise of private-sector digital currencies worldwide, is the accounting nature of these currencies. In a recent official report, the Committee on Payments and Market Infrastructures - the international standards setter the international standard setter for payment systems - states several times that such currencies are not a liability of any individual or any institution (CPMI, 2015), whereas a digital currency issued by a central bank would be a central bank's liabilities (CPMI, 2018) - an apparent inconsistency. The Accounting View resolves such inconsistency clarifying that in both cases the currency represents equity capital of the issuing entity. The application of such conclusion would greatly assist national monetary and financial authorities in shaping transparent regulations in the area of digital currencies.

\section{Empirical estimates}

The empirical estimates of the various types of seigniorage discussed in Section 3 have been based on observations from the UK economy during the 2007-2016 period. The UK was chosen for ease of data availability and in consideration of the recent study covering the UK by Bjerg et al. and Macfarlane et al. . Data were extracted from databases of the Bank of England, the UK Royal Mint, and the Federal Reserve Bank of St. Louis. Other data were taken from the Bank of England accounts. In order to parameterize primary and secondary seigniorage to relatable economic variables, the tables below report stock values are reported in the tables below as a ratio to public debt, on a year-to-year basis, and flow values as a ratio to tax revenues (see the Appendix for details on the methodology adopted).

Concerning commercial bank primary seigniorage, two different estimation procedures were followed. One is a flow-estimation built on the assumption that agents know with certainty 
the share of demand deposits that will be converted into cash and central bank reserves. The other procedure provides a stock-estimation and is based on the aforementioned probabilistic approach and the related belief that the share of demand deposits that will be converted into cash or reserves is known only with some probability. The stock-estimation is expressed as a ratio to the public debt, while the flow-estimation is expressed as a ratio to tax revenues.

Table 1 shows the stock values of the types of money considered in this study, that is, cash, central bank reserves, demand deposits and Commercial Bank Primary Seigniorage (equitydeposits). The average value of cash calculated across the observation period is $5.04 \%$, while the average value of central bank reserves and demand deposits is $13.30 \%$ and $97.18 \%$, respectively. The cash aggregate decreased progressively from 2007 to 2014, and then increased in the following two years. Central bank reserves increased from 2007 to 2010, decreased in 2011, and then increased progressively until 2016. Finally, demand deposits decreased from 2007 to 2012, and then increased from 2013 to 2016. Commercial Bank Primary Seigniorage, as equity deposits, represents $68.58 \%$ of the public debt (average value).

Table 2 shows the primary seigniorage estimated on the monetary aggregates above. Primary Seigniorage on Coins has an average value of $0.02 \%$, while Primary Seigniorage on Notes is $0.55 \%$. The highest average values are those of Primary Seigniorage on Central Bank Reserves (5.74\%) and Commercial Bank Primary Seigniorage (7.66\%). Primary Seigniorage on Coins does not seem to have a regular trend, and Primary Seigniorage on Central Bank Reserves changes considerably also as a consequence of the Quantitative Easing operations undertaken by the Bank of England in response to the crisis. Commercial Bank Primary Seigniorage, too, shows different values from year to year, with the highest being recorded at period end: $15.76 \%$ (2014), $12.37 \%$ (2015) and 20.98\% (2016).

Table 3 shows the estimates of secondary seigniorage. The first column shows the average values calculated over the period, and the second column shows the values as a ratio to tax revenues. Both the Secondary Seigniorage on Notes as well as the Secondary Seigniorage on Central Bank Reserves tend to decrease over the period considered (the former is $0.33 \%$ in 2007 and $0.08 \%$ in 2016, and the latter is $0.02 \%$ in 2007 and $0.01 \%$ in 2016). On the other hand, Secondary Commercial Bank Seigniorage increase from 1.46\% in 2007 to considerably high values at period end (4.25\% in 2014 and $2.39 \%$ in 2015).

These estimates show that, when using correct accounting principles, seigniorage - in particular that extracted by commercial banks - is a quantitatively relevant phenomenon. Macfarlane et al. come to similar conclusions. Yet our results differ from theirs, due to the different theoretical understanding of demand deposits, and most notably their hybrid (double) nature discussed in Section 3,B: first of all, they disregard the primary seigniorage deriving from equity-deposits; second, since they do not distinguish between debt-deposits and equity-deposits, they use total deposits as the base for calculating secondary seigniorage and thus over-estimate it. According to their results, UK annual average commercial bank seigniorage averages $£ 23.3$ billion (calculated over 1998-2016 period). By applying net interest margins to equity-deposits only, our study reports a much lower average of $£ 14.2$ billion (calculated over 2007-2016). 
Table 1 Money stocks (2007-2016)

\begin{tabular}{|l|l|l|}
\hline Stock & $\begin{array}{l}\text { Average Value } \\
(£ \text { bn })\end{array}$ & $\begin{array}{l}\text { Average value } \\
(\% \text { of UK Public } \\
\text { Debt })\end{array}$ \\
\hline Cash (Coins and Notes) & 61.5 & 5.04 \\
\hline Central Bank Reserves & 190.9 & 13.3 \\
\hline Demand Deposits & $1,186.9$ & 97.18 \\
\hline $\begin{array}{l}\text { Commercial Bank Pri- } \\
\text { mary Seigniorage (eq- } \\
\text { uity deposits) }\end{array}$ & 837.59 & 68.58 \\
\hline
\end{tabular}

Table 2 Primary Seigniorage (2007-2016)

\begin{tabular}{|l|l|l|}
\hline Seigniorage & $\begin{array}{l}\text { Average Value } \\
(£ \text { bn })\end{array}$ & $\begin{array}{l}\text { Average value } \\
(\% \text { of UK Tax } \\
\text { Revenues })\end{array}$ \\
\hline $\begin{array}{l}\text { Primary Seigniorage on } \\
\text { Coins }\end{array}$ & 0.09 & 0.02 \\
\hline $\begin{array}{l}\text { Primary Seigniorage on } \\
\text { Notes }\end{array}$ & 3.0 & 0.55 \\
\hline $\begin{array}{l}\text { Primary Seigniorage on } \\
\text { Central Bank Reserves }\end{array}$ & 30.6 & 5.74 \\
\hline $\begin{array}{l}\text { Commercial Bank Pri- } \\
\text { mary Seigniorage }\end{array}$ & 44.7 & 7.66 \\
\hline
\end{tabular}

Table 3 Secondary seigniorage (2007-2016)

\begin{tabular}{|l|l|l|}
\hline Seigniorage & $\begin{array}{l}\text { Average Value } \\
(£ \text { bn })\end{array}$ & $\begin{array}{l}\text { Average value } \\
(\% \text { of UK Tax Rev- } \\
\text { enues })\end{array}$ \\
\hline $\begin{array}{l}\text { Secondary Seigniorage } \\
\text { on Notes }\end{array}$ & 1.1 & 0.2 \\
\hline $\begin{array}{l}\text { Secondary Seigniorage } \\
\text { on Central Bank Re- } \\
\text { serves }\end{array}$ & 0.1 & 0.02 \\
\hline $\begin{array}{l}\text { Commercial Bank Sec- } \\
\text { ondary Seigniorage }\end{array}$ & 14.2 & 2.62 \\
\hline
\end{tabular}

\section{Conclusion}

Based on the correct application of international accounting principles, this study has argued that state monies - in the form of legal tender and central bank money - are not debt, and that in a fractional reserve regime only a share of commercial bank money can be regarded as debt. 
Proceeding separately for the two broad types of money, the study has determined the correct way to account for them in the financial statements of the issuing institutions, clarifying what the different accounting treatment implies for a correct understanding of the various forms of money, and laying the foundations for what we have labeled the "Accounting View" of Money. Importantly, this new view throws light into such issues as the nature of central bank capital, the nature of commercial bak money as hybrid instruments, the nature of commercial banks as hybrid institutions (partly pure intermediaries and partly money creators), and the apparent inconsistency on the accounting nature of private-sector digital currencies.

Furthermore, drawing on the implications of the new approach, the study has derived new measurements of the seigniorage extracted by the state, the central bank, and commercial banks, respectively, and has applied them to the UK (for which previous estimates are available). The results have revealed that seigniorage, in particular that extracted by the commercial banking sector, is a quantitatively relevant phenomenon that deserves further research.

More broadly, the study has aimed to resolve this apparent inconsistency between the formal rules of reporting money liabilities in the financial statements of the issuing institutions, on the one hand, and the economic substance of the money liabilities to be reported in the statements, on the other. Resolving this inconsistency requires a deep interaction between Accounting and Economics the underlying intent of this study. The general lack of communication between the two disciplines has caused the inconsistency to persist unaddressed for decades.

\section{Appendix: Methodological Notes}

This Appendix describes the calculation procedures adopted to estimate the various types of seigniorage discussed in this study. The data used and the sources from where data were drawn. The estimates refer to the 2007-2016 period, except for those that relate to the Commercial Bank Secondary Seigniorage, for which the latest data available is for year 2015.

In order to parameterize primary and secondary seigniorage to relatable economic (stock and flow) variables, they have been expressed as ratios to public debt and tax revenues, respectively. The data on public debt were collected from the "UK government debt and deficit: September 2017" Statistical Bulletin, issued by the UK Office for National Statistics. The data on tax revenues were collected from the "UK Tax Revenues" database of the OECD (https://stats.oecd.org/Index.aspx?DataSetCode=REVGBR).

\section{Primary Seigniorage on Coins}

The total value of coins issued per year were derived from the yearly quantity of coins issued per each of the 8 coin denominations (from $£ 2$ to $1 \mathrm{p}$ ) as reported by the UK Royal Mint (https://www.royalmint.com/discover/uk-coins/circulation-coin-mintage-figures/two-pounds-to20p-issued/; https://www.royalmint.com/discover/uk-coins/circulation-coin-mintage-figures/10pto-half-penny-issued/). Since the Royal Mint does not reveal information on the cost of pro- 
duction of coins, for purpose of estimate this was assumed to be half the value of the coins issued.

\section{Primary Seigniorage on Notes}

Primary seigniorage on banknotes stems from the issue value of new notes in any given year net of their production cost, and it is calculated as the difference between the stock of notes in circulation in any two consecutive years, net of the cost of production of the new notes.

The following items have been used for the purpose of this calculation:

1. Stock of notes in circulation: these are reported among the liabilities in the Bank of England Issue Department statement of balances

2. Production costs and other expenses: these are reported in the Bank of England Issue Department income statements accounts.

Thus,

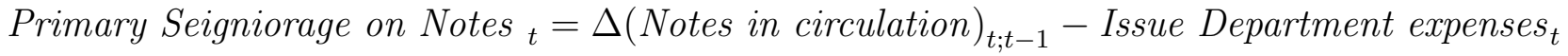

Secondary Seigniorage on Notes

This was taken directly from the Bank of England Issue Department income statement accounts, where income and profits arising from the assets corresponding to the notes in circulation are reported. Reference is made to the two accounting items "Income from securities of, or guaranteed by, the British Government" and "Income from other assets including those acquired under reverse repurchase agreements". These incomes and profits are returned to HM Treasury. Hence:

\section{Secondary Seigniorage on Notes $=$}

Income from securities of, or guaranteed by, the British Government + Income from other assets including those acquired under reverse repurchase agreements

\section{Primary Seigniorage on Central Bank Reserves}

This is calculated as the yearly change in central bank reserves,

Primary Seigniorage on Central Bank Reserves $t=R E S_{t}-R E S_{t-1}$

Data on reserves (RES) were drawn from Bank of England statistical database (code LPMBL22). 


\section{Secondary Seigniorage on Central Bank Reserves}

Since 2006, the Bank of England has paid interest to commercial banks on their holding of central bank reserves, which is equal to the rate of interest Bank of England earns on the assets that correspond to the reserves. Consequently, the creation of new central bank reserves turns out to be revenue-neutral, since there is no seigniorage income earned on them.

On the other hand, the so-called Cash Ratio Deposits (CRDs) are non-interest-bearing deposits lodged with the Bank of England by eligible institutions (i.e. banks and building societies), who have reported average eligible liabilities (ELs) in excess of $£ 600$ million over a six-month calculation period. The level of each institution's CRDs is calculated twice yearly (in May and November) at $0.18 \%$ of average ELs in excess of $£ 600$ million over the previous six end-calendar months. These reserves generate seigniorage, since Bank of England can invest these funds in interest yielding assets (mainly government bonds) and the interest earned is used to fund the costs of its monetary policy and financial stability operations. Under the Bank of England Act 1998, the percentage used in calculating the Cash Ratio Deposits is set by HM Treasury, having regard to the financial needs of the Bank and subject to the approval of both Houses of Parliament. If the Bank of England did not impose this requirement, the government would have to fund the cost of monetary policy and financial stability operations in some other way (for instance, via taxation) (Macfarlane et al.).

The data on CRDs were drawn from Bank of England Financial Statements Notes to the Banking Department Financial Statements. The average return on CRD investments were taken from the HM Treasury Reviews of the Cash Ratio Deposit scheme issued in 2013 and 2018. Average investment yield on CRD deposits over the period March 2008-February 2013 was 4.25 per cent, while average annual investment yield on CRD deposits over the period March 2013- February 2018 was 2.7 per cent. Considering that CRDs are zero-cost reserves, as Bank of England does not pay any interest on them to commercial banks, Secondary Seigniorage on Central Bank Reserves is calculated as:

\section{Secondary Seigniorage on Central Bank Reserves ${ }_{t}=$ $\mathbf{C R D s}_{t} \times$ Average return on CRD investments}

\section{Commercial Bank Primary Seigniorage}

In line with the discussion in Section 3.B, this is calculated only on equity-deposits. Two different estimation procedures were adopted. One is based on the assumption that the share of demand deposits that will be converted into cash and central bank reserves is known with certainty. Accordingly, equity-deposits are calculated simply by subtracting reserves and notes and coins from the total demand deposits aggregate. Considering that notes and coins deposited (and therefore not in circulation) are not part of M1, they have to be subtracted twice. As seigniorage is calculated in flow terms, 


\section{Commercial Bank Primary Seigniorage $e_{t}=\Delta[M 1-(2 M 0)-R E S]_{t ; t-1}$}

where:

1. M0: currency in circulation (notes and coins)

2. M1: M0 + demand deposits

3. RES: reserves held at the central bank.

The second estimation procedure reflects the probabilistic approach discussed in Section 3.B, whereby the share of demand deposits that will be converted into cash or reserves (debtdeposits) is known only with some probability. Here, this probability is calculated as

$$
\text { Probability of debt-deposits }=(M 0+R E S) / \text { demand deposits }
$$

where the value of the ratio on the RHS of the equation is the average of the ratio values observed during the given period. This way of calculating the probability is justified on the ground that the observed data on the money aggregates reveal the agent preferences between cash and demand deposits as well as the commercial banks' demand for central bank reserves. ${ }^{20}$ Based on past observations and looking forward, therefore, the ratio on the RHS of the equation above should indicate how much of total demand deposits should be expected to be converted into cash and reserves each year. Obviously,

$$
\text { Probability of equity-deposits }=1 \text { - probability of debt-deposits. }
$$

For prudential purposes, this value can be corrected for uncertainty by subtracting from it the variability of the $(\mathrm{M} 0+\mathrm{RES}) /$ demand deposit series,

$$
\text { Corrected probability of equity-deposits }=(1-\text { probability of debt-deposits })-\sigma
$$

and, finally,

$$
\begin{gathered}
\text { Commercial Bank Primary Seigniorage }_{t}= \\
\text { Demands } \text { Deposits }_{t} \times \text { Corrected probability of equity-deposits }
\end{gathered}
$$

To identify the monetary aggregates, the following Bank of England data were used:

\footnotetext{
20 The latter, however, is subject to identification problems, since central banks reserves are supply-driven and banks, collectively, are bound to hold any amount of reserves that the central bank supplies. Statistics on reserves, therefore, can hardly be used to proxy commercial banks' demand for them. This is even more evident in times of Quantitative Easing, where commercial banks had simply to hold all excess reserves deliberately created by the central banks for policy purposes. Yet, since when estimating equity-deposits a good practice would require to be conservative, any over-estimation of commercial banks' demand for reserves would ensure extra conservatism in the estimation procedures.
} 
1. Notes and coins: monthly average amount outstanding of total sterling notes and coins in circulation, excluding backing assets for commercial banknote issue in Scotland and Northern Ireland total not seasonally adjusted. Source: Bank of England Statistical database (code LPMAVAA).

2. Central Bank Reserves: monthly average of amounts outstanding (on Wednesdays) of Bank of England Banking Department sterling reserves balance liabilities (in sterling millions) not seasonally adjusted. Source: Bank of England statistical database (code LPMBL22).

3. Demand deposits: quarterly amounts outstanding of monetary financial institutions' sterling and all foreign currency M1 liabilities to private and public sectors not seasonally adjusted (UK estimates of EMU aggregate). Source: Bank of England Statistical database (code LPQVWYE).

For each series, all data were averaged over each year.

\section{Commercial Bank Secondary Seigniorage}

Defined as the net retained earnings originated from equity-deposits, Commercial Bank Secondary Seigniorage was estimated based on the two estimations of equity-deposits derived above. Thus,

Commercial Bank Secondary Seigniorage $_{t}=[M 1-(2 M 0)-R E S]_{t} \times$ net interest margin

and

\section{Commercial Bank Secondary Seigniorage ${ }_{t}=$}

(Demands Deposits D $\times$ Corrected probability of equity-deposits $) \times$ net interest margin

Net interest margin is the difference between the interest income earned and the interest paid by a bank or financial institution relative to its interest-earning assets. Data concerning net interest margin were collected from the database of Federal Reserve Bank of St. Louis (https://fred.stlouisfed.org/series/DDEI01GBA156NWDB).

The results from the two estimation procedures are substantially converging.

A final notation. As discussed in Section 3.B, the estimation of Commercial Bank Secondary Seigniorage should take into consideration the explicit and implicit costs associated with commercial bank borrowing from the central bank for payment settlement purposes. The former derive from the interest rates charged on overnight lending operations, while the latter derives from the opportunity cost of immobilizing resources as collateral to be pledged with the central bank for intra-day borrowing. Due to data limitation purposes, these cost factors have not been included in this study's estimation procedures. However, as also noted by Macfarlane et 
al. , during the period observed, especially after 2009, the massive increase in the quantity of reserves in the banking system has reduced dramatically the borrowing activity of commercial banks.

\section{References}

Arby, M. F., (2006). Seigniorage Earnings of Commercial Banks and State Bank of Pakistan, Munich Personal RePEc Archive.

Archer, D., Moser-Boehm, P., (2013). Central Bank Finances. BIS Papers, 71, Bank for International Settlements, 29 April.

Baltensperger, E., Jordan, T.J., (1997a). Principles of Seigniorage. Swiss Journal of Economics and Statistics, 133 (II), 133-152.

Baltensperger, E., Jordan, T.J., (1997b). Seigniorage, Banking, and the Optimal Quantity of Money. Journal of Banking \& Finance, 21, 781-796.

Beatty, A, Liao, S., (2014). Financial accounting in the banking industry: A review of the empirical literature. Journal of Accounting and Economics, 58, 339-383.

Bjerg, O., McCann, D., Macfarlane, L., Nielsen, R.H., Ryan-Collins J., (2017). Seigniorage in the 21st Century: A study of the profits from money creation in the United Kingdom and

Denmark. CBS Working Paper, January.

Bossone, B., (2000). What Makes Banks Special? A Study of Banking, Finance, and Economic Development. Policy Research Working Paper, 2408, World Bank, Washington, DC.

Bossone, B., (2001). Circuit theory of banking and finance. Journal of Banking and Finance, 25, 857-890.

Buiter, W., (2008). Can central banks go broke? CEPR Policy Insight, 24, May.

Burdekin, R. C. K., (2009). Seigniorage. In: Reinert, K.A., Rajan, R.S., Glass, A.J., Davis, L.S. (Eds.), The Princeton Encyclopedia of the World Economy. Princeton University Press.

Cardoso, E., (2003). Seignorage, Reserve Requirements, and Spreads in Brazil. In: Honohan, P. (ed.), Taxation of Financial Intermediation: Theory and Practice for Emerging Economies.

World Bank and Oxford University Press, 241-267.

Costa, M., (2009). Sulla natura contabile delle "passività monetarie" nei bilanci bancari. Quaderni Monografici Rirea, 85, Roma.

CPMI, (2015). Digital currencies. Committee on Payments and Market Infrastructures. Bank for International Settlements, Novembe.

CPMI, (2018). Central bank digital currencies. Committee on Payments and Market Infrastructures and Markets Committee, Bank for International Settlements, March.

Davidson, P., (1972). Money and the Real World. The Economic Journal, 82, 325 (Mar.), $101-115$.

ESA, (2010). European System of Accounts. Eurostat, European Commission.

Graziani, A., (2003). The Monetary Theory of Production. Cambridge University Press, Cambridge UK. 
Groeneveld, H., Visser, A., (1997). Seigniorage, Electronic Money and Financial Independence of Central Banks. PSL Quarterly Review, 50.

Haslag, J. H., (1998). Seigniorage Revenue and Monetary Policy Economic Review . Third Quarter, Federal Reserve Bank of Dallas.

IASB, (2018). Conceptual Framework for Financial Reporting: IFRS Conceptual Framework. International Accounting Standards Board, IFRS Foundation, March.

Maheswari, S. N., (2013). Principles of Financial Accounting. Vikas Publishing House.

Macfarlane, L., Ryan-Collins, J., Bjerg, O., Nielsen, R., McCann, D., (2017). Making Money from Making Money - Seigniorage in the Modern Economy. New Economics Foundation, Copenhagen Business School.

McLeay, M., Radia, A., and Thomas, R., (2014). Money Creation in the Modern Economy. Bank of England Quarterly Bulletin, 54, 14-27.

PWC, (2017). Distinguishing liabilities from equity. Price Waterhouse Cooper.

PAAinE, (2008). Distinguishing between Liabilities and Equity. Pro-Active Accounting in Europe, Discussion Paper.

Moore, B., (1979). The Endogenous Money Stock. Journal of Post Keynesian Economics, 2, 49-70.

Moore, B., (1983). Unpacking the Post Keynesian Black Box: Bank Lending and the Money Supply. Journal of Post Keynesian Economics, 5, 537-556.

Schmidt, M., (2013). Equity and Liabilities. A Discussion of IAS 32 and a Critique of the Classification. Accounting in Europe, 10, 201-222.

Soldatos, G. T., Varelas E., (2015). On the Quantity Theory of Money, Credit, and Seigniorage. The International Journal of Business and Finance Research, 9, 93-102.

Ryan-Collins, J., Greenham, T., Werner, R., and Jackson, A., (2011). Where Does Money Come From? New Economics Foundation, London.

Turner, A., (2013). Credit, Money and Leverage: What Wicksell, Hayek And Fisher Knew and Modern Macroeconomics Forgot. Lecture. In: Towards a Sustainable Financial System Conference.

Werner, R. A., (2014). How do banks create money, and why can other firms not do the same? An explanation for the coexistence of lending and deposit-taking. International Review of Financial Analysis, 36, 71-77. 